Jurnal Manajemen dan Bisnis, Volume 3, No. 1, Juli 2021

\title{
PENGARUH PERPUTARAN PIUTANG USAHA DAN PERSEDIAAN TERHADAP RETURN ON ASSET PADA PERUSAHAAN AGRIBISNIS YANG GO PUBLIK
}

\author{
Diana Setiyo Dewi \\ Sekolah Tinggi Ilmu Ekonomi Jayakarta \\ diana-wati@stie.jayakarta.ac.id
}

\begin{abstract}
ABSTRAK
Tujuan pertama penelitian ini dilakukan untuk mengetahui pengaruh perputaran piutang usaha terhadap Return on Asset (ROA) pada perusahaan Agribisnis yang Go Publik periode 20172019. Kedua, untuk mengetahui pengaruh perputaran persediaan terhadap Return on Asset (ROA) pada perusahaan Agribisnis yang Go Publik periode 2017-2019. Ketiga, untuk mengetahui pengaruh piutang usaha dan persediaan secara simultan berpengaruh terhadap Return on Asset (ROA) pada perusahaan Agribisnis yang Go Publik periode 2017-2019. Penelitian ini menggunakan data sekunder dimana peneliti menggunakan data dokumentasi yang berada di Indonesian Capital Market Directory (ICMD) tahun 2017-2019. Jenis penelitian ini adalah kuantitatif. Hasil penelitian menunjukan Perputaran piutang usaha berpengaruh negatif terhadap return on asset dengan $\mathrm{t}$ hitung $>\mathrm{t}$ table atau $1,289>-2,000758$. Perputaran persediaan tidak berpengaruh terhadap return on asset dengan thitung $<\mathrm{t}$ table atau 1,289 > -2,000758. Perputaran piutang usaha dan persediaan tidak berpengaruh terhadap return on asset dengan $\mathrm{f}$ hitung $>\mathrm{f}$ table atau 2,383 $>3,17$. Diharapkan dalam mengembangkan ilmu manajemen keuangan yang secara empiris mengenai perputaran piutang usaha dan perputaran persediaan terhadap return on asset dapat menambah variabel independen yang lebih banyak dan berpengaruh terhadap return on asset, sehingga hasilnya dapat digunakan bagi dunia pendidikan dan juga bagi pelaku usaha dalam melaksanakan kegiatan manajemen pengelolaan perusahaannya.
\end{abstract}

Kata Kunci : Perputaran Piutang Usaha, Persediaan, Return on Asset

\begin{abstract}
The first objective of this study was to determine the effect of accounts receivable turnover on return on assets (ROA) in Go Public Agribusiness companies for the 2017-2019 period. Second, to determine the effect of inventory turnover on return on assets (ROA) in Go Public Agribusiness companies for the 2017-2019 period. Third, to determine the effect of accounts receivable and inventories simultaneously affect return on assets (ROA) in agribusiness companies that go public in the 2017-2019 period. This study uses secondary data where researchers use documentation data in the Indonesian Capital Market Directory (ICMD) 2017-2019. This type of research is quantitative. The results showed that accounts receivable turnover had a negative effect on return on assets. Inventory turnover has no effect on return on assets. Accounts receivable and inventory turnover has no effect on return on assets, with $t$ count $\langle t$ table or $1.289>-2.000758$. Accounts receivable and inventory turnover has no effect on return on assets with $f$ count $>f$ table or $2.383>3.17$. It is expected that in developing financial management science that empirically concerns the turnover of trade receivables and the turnover of inventory to return on assets can add more independent variables and affect the return on assets, so that the results can be used for the world of education and also for businesses in carrying out management activities of the company's management.
\end{abstract}

Keywords: Accounts Receivable Turnover, Inventory, Return On Asset 


\section{PENDAHULUAN}

Faktor pertama yang berpengaruh terhadap return on assets yaitu perputaran piutang usaha. Perputaran piutang usaha merupakan rasio yang digunakan untuk mengukur berapa lama penagihan piutang menjadi kas selama periode tertentu. Tinggi rendahnya perputaran piutang usaha mempunyai efek yang langsung terhadap besar kecilnya dana yang diinvestasikan pada piutang. Jika tingkat perputaran piutang tinggi berarti pengembalian dana yang tertanam dalam piutang berlangsung cepat sehingga risiko kerugian piutang dapat diminimalkan.

Tanpa adanya piutang usaha dan persediaan bagaimana suatu perusahaan menjalankan usahanya dan mendapatkan keuntungan. Semakin tinggi nilai perputaran piutang usaha menunjukkan perusahaan telah menerapkan kebijakan pengumpulan piutang yang baik dan efisien. Begitupun dengan perputaran persediaan, apabila laju perputaran persediaan dalam perusahaan tinggi, maka perusahaan akan mendapatkan peningkatan penjualan, otomatis jika penjualan meningkat maka laba perusahaan juga akan meningkat.

Faktor kedua yang berpengaruh terhadap return on assets yaitu perputaran persediaan. Perputaran persediaan adalah perputaran persediaan menjukkan berapa kali persediaan yang dimiliki perusahaan diganti atau dijual selama periode tertentu. Rasio perputaran persediaan adalah mengukur berapa kali persediaan perusahaan yang telah terjual selama periode tertentu, sedangkan jumlah hari persediaan menunjukkan berapa lama persediaan itu tersimpan dalam gudang. Perputaran persediaan dalam perusahaan menunjukkan kinerja perusahaan dalam aktivitas operasionalnya. Semakin tinggi tingkat perputaran persediaan, kemungkinan semakin besar perusahaan akan memperoleh keuntungan. Begitu pula sebaliknya, jika tingkat perputaran persediaannya rendah maka kemungkinan semakin kecil perusahaan akan memperoleh keuntungan.

Penulis meneliti perusahaan yang bergerak di bidang Agribusiness yang terdaftar di Bursa Efek Indonesia khususnya yang sudah Go Public sebagai objek penelitian. Perusahaan-perusahaan agribusiness tersebut dalam kegiatan bisnisnya adalah memproduksi CPO (minyak sawit) dan PK (inti sawit) menjadi produk industri dan konsumen seperti minyak goreng, margari, shortening, karena perusahaan-perusahaan tersebut merupakan perusahaan yang memproduksi bahan dasar yang sangat dibutuhkan oleh masyarakat sehingga perputaran persediaan relatif tinggi. Persediaan yang dijual tersebut menghasilkan piutang usaha karena terjadinya penjualan kredit, persediaan yang relatif tinggi dan dibarengi dengan perputaran piutang usaha yang relatif tinggi akan memengaruhi laba bersih, terutama dalam mengukur efektifitas asset.

Berdasarkan uraian di atas, maka penelitian ini penyusun akan meneliti tentang "Pengaruh Perputaran Piutang Usaha dan Persediaan terhadap Return on Asset (ROA) pada Perusahaan Agribisnis yang Go Publik Periode 2017-2019”. 


\section{KAJIAN LITERATUR}

Agency theory mendasarkan hubungan kontrak antar anggota-anggota dalam perusahaan, dengan principal (prinsipal) dan agent (agen) sebagai pelaku utama. Prinsipal merupakan pihak yang memberikan mandat kepada agen untuk bertindak atas nama prinsipal, sedangkan agen merupakan pihak yang diberi amanat oleh prinsipal untuk menjalankan perusahaan. Agen berkewajiban untuk mempertanggungjawabkan apa yang telah diamanahkan oleh prinsipal kepadanya. Hubungan keagenan muncul ketika satu atau lebih prinsipal mempekerjakan agen untuk memberikan suatu jasa dan kemudian mendelegasikan wewenang pengambilan keputusan kepada agen tersebut. Hubungan prinsipal dan agen ini dalam perusahaan diwujudkan dalam hubungan antara manajer dan pemegang saham. Manajer dianggap sebagai agen dan pemegang saham sebagai prinsipal. Hal ini mampu menimbulkan suatu kontrak antara prinsipal dan agen. Manajer sebagai pengelola perusahaan lebih banyak mengetahui informasi internal dan prospek perusahaan di masa yang akan datang dibandingkan pemilik (pemegang saham).

\section{Faktor-faktor yang Memengaruhi Besar}

\section{Kecilnya Piutang}

Perputaran piutang yang dimiliki suatu perusahaan mempunyai hubungan yang erat dengan jumlah penjualan kredit, sehingga didalam usaha pengendalian piutang dilakukan oleh perusahaan adalah melalui kebijaksanaan kredit yaitu harus memperhatikan tentang besarnya kebijaksanaan penjualan kredit yang dilakukan oleh perusahaan terhadap hasil produksinya. Menurut Bambang Riyanto (2016: 85), ada beberapa faktor-faktor yang dipengaruhi besar kecilnya piutang, yaitu: a. Volume Penjualan Kredit

Makin besar volume penjualan kredit yang dilakukan, makin besar pula investasi yang ditanamkan dalam piutang. Semakin besarnya volume penjualan kredit tiap tahunnya berarti perusahaan itu harus menyediakan investasi lebih besar lagi dalam piutang. Makin besar jumlah piutang berarti semakin besar resikonya, tetapi bersamaan dengan itu juga memperbesar profitabilitasnya.

b. Syarat Pembayaran Penjualan Kredit

Syarat pembayar penjualan kredit dapat bersipat ketat atau lunak. Apabila perusahaan menetapkan syarat pembayaran yang ketat berarti perusahaan lebih mengutamakan keselamatan kredit daripada profitabilitasnya. Semakin panjang batas waktu pembayaran kredit berarti semakin besar jumlah piutangnya.

c. Ketentuan tentang Pembatasan Kredit

Pembatasan kredit juga harus ditetapkan oleh perusahaan dalam memberikan kredit. Makin tinggi pembatasan kredit yang ditetapkan bagi masing-masing langganan, berarti semakin besar pula dana yang diinvestasikan dalam piutang.

d. Kebijakan dalam Mengumpulkan Piutang

Kebijakan pengumpulan piutang oleh perusahaan dapat dilakukan secara aktif maupun pasif. Apabila perusahaan menerapkan kebijaksanaan pengumpulan piutang secara aktif, artinya perusahaan melakukan penagihan sendiri, maka perusahaan akan mengeluarkan biaya yang lebih besar. Namun hal ini berbeda jika perusahaan menerapkan pengumpulan piutang secara pasif, maka investasi yang ditanamkan dalam piutang akan lebih besar.

e. Kebiasaan Membayar dari Para Pelanggan

Kebiasaan membayar ini menyangkut pemenfaatan discount period oleh pelanggan, artinya semakin langganan ini memanfaatkan discount period, semakin kecil investasi yang ditanamkan dalam piutang.

\section{Kelebihan dan Kelemahan Return on} Assets (ROA) 
Adapun kelebihan dan kelemahan Return on Asset adalah sebagai berikut:

a. Kelebihan ROA diantaranya sebagai berikut:

1) ROA mudah dihitung dan dipahami.

2) Merupakan alat pengukur prestasi manajemen yang sensitif terhadap setiap pengaruh keadaan keuangan perusahaan.

3) Manajemen menitikberatkan perhatiannya pada perolehan laba yang maksimal.

4) Sebagai tolok ukur prestasi manajemen dalam memanfaatkan asset yang dimiliki perusahaan untuk memperoleh laba.

5) Mendorong tercapainya tujuan perusahaan.

6) Sebagai alat mengevaluasi atas penerapan kebijakan-kebijakan manajemen.

b. Kelemahan ROA diantaranya sebagai berikut:

1) Kurang mendorong manajemen untuk menambah asset apabila nilai ROA yang diharapkan ternyata terlalu tinggi.

2) Manajemen cenderung fokus pada tujuan jangka pendek bukan pada tujuan jangka panjang, sehingga cenderung mengambil keputusan jangka pendek yang lebih menguntungkan tetapi berakibat negatif dalam jangka panjangnya.

\section{METODE PENELITIAN}

Jenis penelitian berdasarkan tujuannya yang digunakan dalam penelitian ini:

1. Penelitian Deskriptif

Pengertian Penelitian deskriptif adalah Penelitian yang menekankan upaya untuk mendeskripsikan peristiwa, kejadian, gejala yang sedang terjadi. Metode deskriptif berupaya untuk mendeskripsikan dan mengidentifikasi mengapa, apa dan bagaimana suatu fenomena atau peristiwa bisa terjadi.

2. Metode Eksplanatori (Explanatory)

Jenis penelitian eksplanatori ini (sering disebut eksplanatif atau eksplenatoris = bersifat menjelaskan, belum ada kata bakunya) atau di sebut juga penelitian verifikatif bertujuan untuk menguji suatu kebenaran melalui pengujian hipotesis tentang sebabakibat antara berbagai variabel yang diteliti. Dalam hal ini dengan sendirinya sudah ada hipotesisnya. Penelitian bersifat menjelaskan ini dapat dilakukan jika pengetahuan tentang masalahnya sudah cukup, artinya sudah ada beberapa teori dan sudah ada berbagai penelitian empiris yang menguji hipotesis tertentu. Jadi jenis penelitian ini selalu bertolak belakang dari suatu hipotesis yang diperoleh dari suatu teori tertentu

Jenis penelitian berdasarkan metodenya yang digunakan dalam penelitian ini:

\section{Penelitian Korelasional}

Pengertian Penelitian korelasional adalah Penelitian yang dilaksanakan dengan cara 
menghubungkan satu variabel dengan variabel lainnya untuk memahami suatu fenomena atau kejadian, dengan cara menentukan tingkat atau derajat hubungan antar variabel-variabel tersebut. Metode ini sangat cocok digunakan pada saat melakukan penelitian mengenai variabel-variabel yang kompleks dan rumit yang tidak akan bisa diselesaikan dengan menggunakan metode eksperimental.

Tingkat hubungan tersebut ditunjukkan oleh nilai koefisien korelasi yang berfungsi untuk membandingkan variabilitas hasil pengukuran terhadap variabel-variabel tersebut. Pengetahuan tentang tingkat hubungan tersebut diharapkan dapat menambah pemahaman tentang faktor-faktor dalam karakteristik yang kompleks dari suatu fenomena.

\section{Penelitian Komparatif (Rasio)}

Penelitian dengan metode rasio adalah suatu penelitian untuk membandingkan antara dua objek guna mengukur tingkat kelayakan suatu variable. Umumnya hipotesis rasio ini digunakan oleh Program S1 jurusan akuntansi.

Berdasarkan sifat datanya, jenis penelitian yang digunakan adalah penelitian kuantitatif. Penelitian kuantitatif, yaitu metodologi kuantitatif sebagai proses penelitian yang menghasilkan data berupa angka-angka dan umumnya dianalisis dengan menggunakan statistik deskriptif atau inferensial. Metode penelitian kuantitatif digunakan untuk meneliti pada populasi atau sampel dengan menggunakan instrument penelitian dengan tujuan untuk menguji hipotesis yang telah dirumuskan

Berdasarkan tempatnya, jenis penelitian yang digunakan yaitu penelitian perpustakaan (Library Research), penelitian perpustakaan ialah pengumpulan data sekunder yang dilakukan dengan jalan membaca buku, majalah, dan sumber data lainnya di dalam perpustakaan. Jadi, usaha pengumpulan data (informasi) dilakukan di tempat tersimpannya buku-buku serta refrensi lainnya. studi kepustakaan diperlukan sebagai salah satu cara untuk memahami gejala-gejala baru yang terjadi yang belum dapat dipahami, kemudian dengan studi kepustakaan ini akan dapat dipahami gejala tersebut. Sehingga dalam mengatasi suatu gejala yang terjadi,

Metode pengumpulan data yang digunakan dalam penelitian ini adalah metode dokumentasi, yaitu menggunakan data dokumentasi yang berada di Indonesian Capital Market Directory (ICMD) tahun 20172019. Serta data tentang informasi laporan keuangan perusahaan agribisnis yang Go Publik yang di BEI dari situs www.idx.co.id.

\section{HASIL DAN PEMBAHASAN}

Populasi dalam penelitian ini adalah seluruh perusahaan manufaktur yang terdaftar di BEI. Pengambilan sampel dalam penelitian ini menggunakan teknik purposive sampling yang merupakan metode pemilihan sampel tidak secara acak yang informasinya diperoleh dengan menggunakan pertimbangan tertentu (Indriantoro dan Bambang, 2012:56). Sampel dalam penelitian ini adalah sebagian seluruh 
perusahaan agribisnis yang Go Publik periode 2017-2019.

Dalam penelitian ini variabel dependen atau terikat $(\mathrm{Y})$ adalah return on asset, selanjutnya variabel independen atau bebas adalah perputaran piutang usaha dan persediaan. Hasil analisis korelasi dan regresi berganda dengan menggunakan SPSS adalah sebagai berikut:

\section{Tabel 4.9 Hasil Koefisien Korelasi}

\section{Simultan}

\begin{tabular}{|r|r|c|}
\hline \multicolumn{1}{|c|}{$\boldsymbol{R}$} & $\boldsymbol{R}$ Square & Adjusted $\boldsymbol{R}$ Square \\
\hline 0,292 & 0,085 & 0,050 \\
$\mathrm{a}$ & & \\
\hline
\end{tabular}

Berdasarkan hasil koefisien korelasi simultan tersebut dapat diketahui bahwa korelasi yang terjadi antara variabel bebas terhadap variabel terikat diketahui nilai $\mathrm{R}=$ 0,292 , hal ini mengindikasikan bahwa variabel bebas perputaran piutang usaha dan persediaan memiliki hubungan terhadap variabel terikat return on asset $(\mathrm{Y})$. NIlai 0,292 berada dalam rentang 0,20 s.d 040, berarti korelasi perputaran piutang usaha dan persediaan dengan return on asset dikategorikan korelasi lemah. Adapun hubungan yang terjadi adalah positif dan searah dengan tingkat hubungan yang lemah.

\section{Pembahasan}

\section{Pengaruh Perputaran Piutang} Usaha terhadap Return on Asset
Perputaran piutang usaha berpengaruh negatif terhadap return on asset pada perusahaan agribisnis yang Go Publik periode 2017-2019. Semakin tinggi perputaran piutang maka return on asset justru akan semakin menurun, hal ini disebabkan karena faktor resiko hutang tak tertagih dan faktor barang produksi yang mudah rusak. Sehingga menimbulkan pengembalian barang dan menyebabkan piutang tak terbayar.

Hal ini dapat dilihat dari hasil statistik deskriptif yang menunjukkan nilai rata-rata sebesar 13,65367 dari nilai minimum 0,007 dan nilai maksimum 71,030 serta nilai variance sebesar 198,535. Nilai tersebut menunjukkan bahwa rata-rata hasil statistik deskriptif yang cenderung berada di rata-rata atas, dapat diartikan bahwa secara umum perputaran piutang yang tinggi diikuti dengan return on asset yang semakin menurun.

Hasil penelitian ini sesuai dengan hasil penelitian Niati, dkk (2019), Ramadani dan Rasyid (2019), I Gusti Ayu Agung Mirah Sanjiwani dan Ketut Alit Suardana (2019), Elvi Bethari Saragih dan Joana L. Saragih (2018) serta Elvi Yanti dan Lidya Martha (2020) menyatakan adanya hubungan antara perputaran piutang usaha dengan return on asset.

\section{Pengaruh Perputaran Persediaan terhadap Return on Asset}

Perputaran persediaan tidak berpengaruh terhadap return on asset pada perusahaan agribisnis yang Go Publik periode 2017-2019. Semakin cepatnya persediaan berputar di 
gudang belum tentu diikuti dengan peningkatan return on asset karena bisa saja penjualan barang tersebut belum terbayar dan menjadi piutang di perusahaan.

Hal ini dapat dilihat dari hasil statistik deskriptif yang menunjukkan nilai rata-rata sebesar 9,72822 dari nilai minimum 0,010 dan nilai maksimum 46,253 serta nilai variance sebesar 9,72822. Nilai tersebut menunjukkan bahwa rata-rata hasil statistik deskriptif yang cenderung berada di rata-rata bawah, dapat diartikan bahwa secara umum semakin cepatnya perputaran persediaan tidak serta merta diikuti dengan peningkatan return on asset.

Untuk mengukur efisiensi persediaan maka perlu diketahui perputaran persediaan (inventory turnover) yang terjadi dengan membandingkan antara harga pokok penjualan (HPP) dengan nilai rata-rata persediaan yang dimiliki. Perputaran persediaan menunjukan berapa kali dana yang tertanam dalam persediaan berputar (diganti) dalam suatu periode, (Munawir, 2014:35).

Hasil penelitian ini sesuai dengan hasil penelitian Ramadani dan Rasyid (2019) serta Septian (2018) mengungkapkan tidak adanya pengaruh antara perputaran persediaan dengan return on asset.

\section{Pengaruh Perputaran Piutang Usaha dan Persediaan terhadap Return on Asset}

Perputaran piutang usaha dan persediaan tidak berpengaruh terhadap return on asset. Berdasarkan nilai $\mathrm{F}$ hitung lebih kecil dari $\mathrm{F}$ tabel $(12,383>3,18)$, serta berdasarkan nilai koefisien signifikansi sebesar 0,002 yang lebih kecil dari 0,05, sehingga dapat disimpulkan bahwa tidak terdapat pengaruh perputaran piutang usaha dan persediaan terhadap return on asset pada perusahaan agribisnis yang Go Publik periode 2017-2019.

Berdasarkan hasil koefisien determinasi tersebut dapat diketahui bahwa korelasi yang terjadi antara variabel bebas terhadap variabel terikat diketahui nilai $\mathrm{r}=0,292^{\mathrm{a}}$, hal ini mengindikasikan bahwa variabel bebas perputaran piutang usaha dan persediaan memiliki hubungan terhadap variabel terikat return on asset (Y). Adapun hubungan yang terjadi adalah positif dan searah dengan tingkat hubungan yang lemah.

Berdasarkan hasil analisis regresi linear berganda tersebut, diketahui bahwa koefisien determinasi yang dinotasikan dengan adjusted $R^{2}$ besarnya 0,339 . Ini berarti variabel return on asset dapat dijelaskan oleh variabel perputaran piutang usaha dan persediaan yang diturunkan dalam model sebesar 5\%, atau dengan kata lain sumbangan efektif (kontribusi) variabel independen terhadap variasi (perubahan) return on asset (Y) sebesar $5 \%$. Variasi return on asset $(\mathrm{Y})$ bisa dijelaskan oleh variasi dari kedua variabel independen, jadi sisanya sebesar $(100 \%-5 \%=95 \%)$ return on asset dijelaskan oleh variabelvariabel lain yang tidak dimasukkan dalam model penelitian ini, misalnya perputaran kas.

Hasil penelitian ini sesuai dengan hasil penelitian Niati, dkk (2019), I Gusti Ayu Agung Mirah Sanjiwani dan Ketut Alit Suardana (2019), Elvi Bethari Saragih dan Joana L. Saragih (2018) serta Elvi Yanti dan 
Lidya Martha (2020) menyatakan adanya hubungan antara perputaran piutang usaha dan persediaan dengan return on asset.

\section{KESIMPULAN}

Berdasarkan olah data dan analisis tentang pengaruh perputaran piutang usaha dan persediaan terhadap return on asset pada perusahaan agribisnis yang Go Publik periode 2017-2019 serta berdasarkan bukti-bukti empiris yang diperoleh maka disimpulkan bahwa:

1. Perputaran piutang usaha berpengaruh negatif terhadap return on asset pada perusahaan agribisnis yang Go Publik periode 2017-2019. Semakin tinggi perputaran piutang maka return on asset justru akan semakin menurun, hal ini disebabkan karena faktor risiko utang tak tertagih dan faktor barang produksi yang mudah rusak. Sehingga menimbulkan pengembalian barang dan menyebabkan piutang tak terbayar.

Adapun nilai penilitian menunjukan angka berikut:

a. Nilai -t hitung < - t tabel atau $2,074<-2,00758$ dan Probalitas $<0,05$ atau $0,043<0,05$, berarti Ho ditolak atau $\mathrm{Ha}$ diterima. Dengan demikian koefisien regresi signifikan atau variabel perputaran piutang usaha $\left(\mathrm{X}_{1}\right)$ benar-benar berpengaruh secara signifikan terhadap variabel return on asset $(\mathrm{Y})$. b. Nilai sig perputaran piutang terhadap return on asset menunjukan nilai $0,043<$ 0,05, maka Ho diterima. Hal ini berarti ada pengaruh yang signifikan antara piutang usaha terhadap return on asset”.

c. Nilai Korelasi parsial antara perputaran piutang usaha dengan return on asset menunjukkan angka sebesar -0,236, berdasarkan data rentang $-0,20$ s.d $-0,40$ dengan demikian korelasi antara perputaran piutang usaha dengan return on asset dikategori hubungan lemah dengan arah negatif..

2. Perputaran persediaan tidak berpengaruh terhadap return on asset pada perusahaan agribisnis yang Go Publik periode 2017-2019.

Adapun nilai penilitian menunjukan angka berikut:

a. Nilai atas $\mathrm{t}$ hitung $<\mathrm{t}$ tabel atau 1,289 < 2,00758, berarti Ho diterima atau Ha ditolak. Dengan demikian koefisien regresi signifikan atau variabel perputaran Persediaan $\left(\mathrm{X}_{2}\right)$ tidak berpengaruh secara signifikan terhadap variabel return on asset (Y).

b. Nilai sig perputaran persediaan dengan return on asset menunjukan nilai $0.203>0,05$, maka Ho diterima. Hal ini berarti tidak ada pengaruh antara persediaan dengan return on asset”.

c. Korelasi parsial antara perputaran persediaan sesuai dengan return on asset menunjukan nilai 0,091 berdasarkan data rentang 0,00 s.d 0,20 dengan demikian korelasi 
antara perputaran persediaan dengan return on asset dikategori hubungan sangat lemah dengan arah positif.

3. Perputaran piutang usaha dan persediaan berpengaruh terhadap return on asset. dengan rincian berikut:

a. Nilai F hitung > F tabel atau 12,383 $>3,18$, berarti Ho ditolak atau $\mathrm{Ha}$ diterima. Dengan demikian koefisien regresi signifikan atau variabel perputaran piutang usaha (X1) dan perputaran persediaan (X2) secara simultan berpengaruh secara signifikan terhadap variabel return on asset (Y).

b. Nilai sig $\mathrm{F}$ antara perputaran piutang dan persediaan terhadap return on asset menghasilkan nilai $0,002<0,05$ berati nilai perputaran hutang $\left(\mathrm{X}_{1}\right)$ dan persediaan $\left(\mathrm{X}_{2}\right)$ secara simultan berpengaruh terhadap return on asset.

c. Nilai Nilai $R=0,292$, hal ini mengindikasikan bahwa variabel bebas perputaran piutang usaha dan persediaan memiliki hubungan terhadap variabel terikat return on asset $(\mathrm{Y})$. Nillai 0,292 berada dalam rentang 0,20 s.d 040, berarti korelasi perputaran piutang usaha dan persediaan dengan return on asset dikategorikan korelasi lemah. d. Nilai koefisien determinasi $=0,085$, yang berarti nilai ini menunjukan bahwa kontribusi dari perputaran piutang dan perputaran persediaan terhadap return on asset adalah sebesar $8,5 \%$.

\section{Saran}

Berdasarkan kesimpulan di atas penulis memberikan saran yang mungkin berguna sebagai dasar pertimbangan atau masukan bagi perusahaan untuk mengatasi kekurangan/kelemahan pelaksanaan tersebut, yaitu sebagi berikut:

1. Saran bagi pengembang ilmu

Diharapkan dengan adanya penelitian ini dapat berguna dalam mengembangkan ilmu manajemen keuangan yang secara empiris mengenai perputaran piutang usaha dan perputaran persediaan terhadap return on asset, sehingga dapat digunakan bagi para pelaku usaha dalam melaksanakan kegiatan manajemen pengelolaan perusahaannya terutama perusahaan Agribisnis yang go public “, penelitian selanjutnya diharapkan menambah variabel independen yang berpengaruh terhadap return on asset misalnya perputaran kas sebagaimana dalam penelitian Okiawan (2018).

\section{Saran Bagi Operasional}

Setelah mengamati dan menganalisa hasil penelitian, penulis melihat hal yang dapat dijadikan masukan bagi perusahaanperusahaan terutama perusahaan Agribisnis yang go public ",dari hasil penelitian 
menunjukan adanya pengaruh dalam mengelola perputaran kas piutang usaha dan perputaran persediaan terhadap return on asset perusahaan. Sehingga perusahaan-perusahaan tersebut dapat lebih mengoptimalkan manajerial dalam mengola arus perputaran kasnya sehingga dapat melakukan antisipasi hal-hal yang tidak diinginkan dalam perjalanan mengelola perusahaan.

\section{DAFTAR PUSTAKA}

Buku:

Brigham, Eugene. F dan Joel F. Houston. 2013. Manajemen Keuangan. Jakarta: Erlangga.

Ghozali, Imam. 2015. Aplikasi Analisis Multivariate dengan Program SPSS. Semarang: BP Undip.

Harahap, Sofyan Syafri. 2016. Analisis Kritis atas Laporan Keuangan. Jakarta: Raja Grafindo Persada.

Ikatan Manajemen Indonesia (IAI). 2018. Pernyataan Standar Manajemen Keuangan (PSAK) No.69: Agrikultur. Jakarta: IAI.

Indriantoro dan Supomo. 2012. Metodologi Penelitian Bisnis untuk Manajemen dan Manajemen. Yogyakarta : BPFE Yogyakarta.

Irawati, Susan. 2016. Manajemen Keuangan. Bandung: Pustaka.
Kasmir. 2015. Analisa Laporan Keuangan. Jakarta: Rajawali Pers.

Munawir. 2014. Analisisa Laporan Keuangan. Yogyakarta: Liberty.

Riyanto, Bambang. 2016. Dasar-Dasar Pembelanjaan Perusahaan. Yogyakarta: BPFE.

Sartono, Agus. 2010. Manajemen Keuangan Teori dan Aplikasi. Yogyakarta: BPFE.

Silaen, Sofar. 2018 Metodologi Penelitian Sosial untuk Penulisan Skripsi dan Tesis, Bogor; In Media.

Jurnal:

Deni, Irman. 2012. "Pengaruh Tingkat Perputaran Kas, Perputaran Piutang dan Perputaran Persediaan Terhadap Profitabilitas Pada Perusahaan Manufaktur yang Terdaftar di Bursa Efek Indonesia”. Jurnal Manajemen. Vol. 1 No. 4: 1-18.

Fitri, Meria. 2013. "Pengaruh Perputaran Piutang Usaha dan Perputaran Persediaan terhadap Tingkat Profitabilitas Perusahaan Otomotif dan Komponen yang Terdaftar di Bursa Efek Indonesia”. Jurnal Ekonomi. Vol. 2 No. 1: 1-9.

Jensen, Michael C. and William H. Meckling, 1976. "Theory Of The Firm: Managerial Behavior, Agency Costs And Ownership Structure". Journal of Financial Economics. Vol. 3: 305-360. 
Jufrizen. 2014. "Pengaruh Perputaran Kas dan Perputaran Persediaan terhadap Profitabilitas Pada Perusahaan Plastik dan Kemasan yang Terdaftar di BEI". Jurnal Ekonomi. Vol. 1 No. 3:131-138.

Kameswari dan Astika. 2014. "Pengaruh Jumlah Opsi Saham dan Harga Eksekusi Pada Kinerja Perusahaan”. E-Jurnal Manajemen. Vol. 9 No. 2:356-372.

Naibaho, Erik Pebrin dan Sri Rahayu. 2016. "Pengaruh Perputaran Piutang dan Perputaran Persediaan terhadap Profitabilitas (Studi Empiris Perusahaan Makanan dan Minuman yang Terdaftar di BEI Tahun 2008-2012)". e-Proceeding of Management. Vol. 1 No. 3: 279-290.

Niati, Atikah Indah, Diah Yudhawati dan Supramono. 2019. "Pengaruh Perputaran Persediaan dan Perputaran Piutang terhadap Return on Asset (ROA) pada Perusahaan Manufaktur Sub Sektor Makanan dan Minuman". Jurnal Ilmu Manajemen. Vol. 2 No. 3: 318-328.

Nurmasari, Ifa dan Yashinta Rifkiawati. 2019. "Perputaran Kas dan Perputaran Piutang pengaruhnya terhadap Return on Asset pada PT Astra International Tbk. Periode 2003-2017”. JIMF (Jurnal Ilmiah Manajemen Forkamma). Vol. 3 No. 1: 61-73.

Ramadani, Dilla dan Rosyeni Rasyid. 2019. "Pengaruh Perputaran Kas, Perputaran Piutang dan Perputaran Persediaan terhadap Profitabilitas pada Perusahaan
Makanan dan Minuman yang Terdaftar di Bursa Efek Indonesia Periode 2013 2017”. Jurnal Kajian Manajemen dan Wirausaha. Vol. 01 No. 01: 96-106.

Sanjiwani, I Gusti Ayu Agung Mirah dan Ketut Alit Suardana. 2019. "FaktorFaktor yang Memengaruhi Profitabilitas Perusahaan Otomotif di Bursa Efek Indonesia”. E-Jurnal Manajemen. Vol. 26 No. 3: 2424-2452.

Saragih, Elvi Bethari dan Joana L. Saragih. 2018. "Pengaruh Perputaran Kas, Perputaran Piutang, dan Perputaran Persediaan terhadap Return on Assets pada Perusahaan Sektor Industri Dasar dan Kimia yang Terdaftar di Bursa Efek Indonesia”. Jurnal Reviu Manajemen dan Keuangan (JRAK). Vol. 4 No. 2: 175-194.

Setyaningrum, Agatha Niken. 2012. "Pengaruh ESOP terhadap Kualitas Implementasi Corporate Governance \& Kinerja Perusahaan (Studi Kasus pada Perusahaan-Perusahaan yang Terdaftar di Bursa Efek Indonesia)", Jurnal Universitas Brawijaya. Vol 1. No. 1: 126.

Utami, Made Sri dan Made Rusmala Dewi. 2016. "Pengaruh Manajemen Modal Kerja terhadap Profitabilitas Perusahaan Manufaktur yang Terdaftar di Bursa Efek Indonesia”. E-Jurnal Manajemen. Vol. 5 No. 6: 3476-3503.

Yanti, Elvi dan Lidya Martha. 2020. "Pengaruh Perputaran Piutang Usaha dan 
Perputaran Persediaan terhadap

Profitabilitas pada Perusahaan Food and

Beverage yang Terdaftar di Bursa Efek

Indonesia". Jurnal Manajemen. Vol. 1

No. 2: 1-14 